Volume 21 Number 2 December 2021. P 302-325

https://doi.org/10.30603/au.v21i2.2380

\title{
The Effect of Inter-Religious Tolerance Development on Students in Gorontalo City
}

\author{
1' Ibnu Rawandhy N. Hula, ${ }^{1}$ Fatimah Djafar, ${ }^{1}$ Mujahid Damopolii \\ ${ }^{2}$ Ana Mariana, ${ }^{3}$ Abdul Rohman \\ 1IAIN Sultan Amai Gorontalo, ${ }^{2}$ Universitas Muhammadiyah Gorontalo, ${ }^{3}$ IN Walisongo Semarang
}

\begin{abstract}
This study describes tolerance among religious communities and intolerant behavior in students. It also tests the hypothesis of whether there is a significant influence between fostering tolerance among religious communities and heterogeneous student behavior in the formal educational institutions in Gorontalo City. The study used quantitative research with a correlation method through a simple regression. Data were collected using a closed questionnaire, which involved 67 students. This study showed that there is a significant influence between fostering religious tolerance and intolerant behavior of students. This influence is shown by the regression coefficient number of F-count 115.577 with a significance level of $5 \%(F$-table $=3.99)$. Besides, the value of determination ( $R$ Square) $=0,640$ illustrates that tolerance among religious communities has a high effect on the tolerance behavior of students. Thus, it can be stated that $64 \%$ of the students' tolerance behavior is affected by the religious communities' tolerance, and the rest (36\%) is influenced by other factors.
\end{abstract}

Keywords: Tolerance, Development, Inter-Religious, intolerance, heterogenous student

\section{Pengaruh Pembinaan Toleransi Antar Umat Beragama Pada Mahasiswa di Kota Gorontalo}

\begin{abstract}
Abstrak
Penelitian ini mendeskripsikan toleransi antar umat beragama dan perilaku intoleran pada siswa. Selain itu, studi ini juga menguji hipotesis apakah terdapat pengaruh yang signifikan antara pembinaan toleransi antarumat beragama dengan perilaku siswa yang hiterogin pada lembaga pendidikan formal di Kota Gorontalo. Studi ini merupakan penelitian kuantitatif dengan metode korelasi melalui regresi sederhana. Pengumpulan data menggunakan angket tertutup dengan melibatkan 67 siswa. Hasil penelitian ini menunjukkan bahwa terdapat pengaruh yang signifikan antara pembinaan toleransi beragama dengan perilaku intoleran siswa. Pengaruh tersebut ditunjukkan oleh angka koefisien regresi F-hitung 115,577 dengan taraf signifikansi 5\% (F-tabel $=3,99)$. Selain itu, nilai determinasi $(R$ Square $)=0,640$ menggambarkan bahwa toleransi antar umat beragama berpengaruh tinggi terhadap perilaku toleransi siswa. Oleh karenanya, dapat dikatakan bahwa 64\% perilaku toleransi siswa dipengaruhi oleh faktor toleransi umat beragama, dan selebihnya (36\%) dipengaruhi oleh faktor lain.
\end{abstract}

Kata-kata kunci: Toleransi, Pembangunan, Antar Umat Beragama, Intoleransi, Mahasiswa Heterogen

Author correspondence

Email: Ibnurawandi@iaingorontalo.ac.id

Available online at http://journal.iaingorontalo.ac.id/index.php/au/index 


\section{A. Introduction}

The problem of tolerance today is still a trending topic ${ }^{12}$ which keeps popping up with various problems,$^{3}$ so it is necessary to find a way to overcome it so that tolerance becomes the basis for building a sustainable human civilization. ${ }^{4}$ Likewise, humans as servants of God, the diversity of individuals with their beliefs in addition to being plural, ${ }^{5}$ also become sunnatullah, which must be respected. ${ }^{6}$ If belief is similar to religious tolerance, then ideally, religious diversity should be built through the active participation of all religious people to achieve the same goal based on togetherness while still adhering to tasamuh. ${ }^{7}$ towards each religious doctrine that is believed ${ }^{8}$ by giving space for the existence of other sociological groups for tolerant exclusivism. ${ }^{9}$

Religious tolerance is a manifestation of the expression of religious experience in the form of togetherness. ${ }^{10}$ As done by Joachim Wach, the expression of religious experience in the form of this group is a human religious response to the absolute reality that is manifested in the form of social order

\footnotetext{
${ }^{1}$ Ichsan Emrald Alamsyah, "Moderasi Beragama dalam Menangkal Paham Radikalisme", Republika, 2021, https://www.republika.co.id/berita/r25c05349/moderasi-beragama-dalam-menangkalpaham-radikalisme. The emergence of the concept of religious moderation, one of which is caused by the problem of intolerance, radicalism and intolerant ways of religion which are marked by the emergence of extremist groups.

2Tim Penulis Laptah, "Laporan Tahunan KOMNAS HAM 2017-2022" (Menteng Jakarta Pusat, 2019),https://www.komnasham.go.id/files/20201209-laporan-tahunan-komnas-ham-2019-

\$V1GFW5HE.pdf."Kasus Intoleran Setiap Tahun Meningkat".

${ }^{3}$ Itsram, "Toleransi Beragama Indonesia: Bagaikan Gajah di Pelupuk Mata", Institut Sepuluh November, 2021, https://www.its.ac.id/news/2021/09/25/toleransi-beragama-indonesiabagaikan-gajah-di-pelupuk-mata/ It is common knowledge that social life in the midst of Indonesia's diversity does not always run smoothly. There are always conflicts that arise due to the sentiments between groups.

${ }^{4}$ Imam Bukhori, "Membumikan Multikulturalisme", HUMANISTIKA : Jurnal Keislaman 5, :(2019) 1 40-13, https://doi.org/10.36835/humanistika.v5i1.40.

5Sofiah, "Dialog sebagai media Integrasi Pluralitas dalam Islam", Al Qodiri : Jurnal Pendidikan, Sosial dan Keagamaan 2, 62-50:2017) 1 .

${ }^{6}$ Haeri Fadly, "Multikultural ( Melacak Konsep Multikulturalisme Dalam Islam )" 3, no. 1 (2010): 71 84.

${ }^{7}$ Fauzi Muharom, "Tasamuh E-Module Development in the Fiqih Subject for 10 th Grade Students in Islamic Senior", Nazhruna: Jurnal Pendidikan Islam 4,46-531 :(2021) 3 , https://doi.org/https://doi.org/10.31538/nzh.v4i3.1617.

${ }^{8}$ M. Zainul Hasani Syarif, "Dinamika Pendidikan Islam Minoritas (Eksistensi, Kontestasi Dan Konvergensi Lembaga Pendidikan Tinggi Muhammadiyah Di Nusa Tenggara Timur) Diajukan" (UIN Syratif Hidayatullah, 2021).

${ }^{9}$ Ahmad Khoirul Fata, "Menguak Islam Eksklusif yang Toleran", ISLAMICA: Jurnal Studi Keislaman 6, 14 :(2014) 1, https://doi.org/10.15642/islamica.2011.6.1.14-24.

${ }^{10}$ Joachim Wach, "The comparative study of religions", A Columbia paperback, 1961.
} 
among people of the same religion or different religions. ${ }^{11}$ While religion as exoteric ${ }^{12}$ created in this world is different. ${ }^{13}$ However, despite the differences that arise in religions, the esoteric religions that exist in this world have the same principle, namely originating and aiming at the Almighty (The Highest). ${ }^{14}$ In line with this research, Schuon distinguishes these two aspects of religion that can be applied to guide how people of different religions meet each other in giving their roles as servants of the One God in this world. ${ }^{15}$

In the context of a religious society, shifts between religions with various dimensions of community social interests often become quite complex issues. The development of religion $(a \text {-gama }=\text { not messed } u p)^{16}$, which should contain guidelines for living in peace with a plurality of adherents, still has the potential to cause conflict on the other side, ${ }^{17}$ although on the other hand, religion can also encourage integration in society. ${ }^{18}$ Even now, different religious traditions between religions are starting to rub against each other, like attitude tadlilli, tabdi'i and takfiri.

The inception of the conflict, apart from being triggered by differences in beliefs and diversity of understanding of normative doctrines ${ }^{19}$ (especially the holy book), ${ }^{20}$ It is also caused by the presence of religion mixed with unlimited political interests, although it is recognized that non-religious factors also have a very high

\footnotetext{
${ }^{11}$ Joachim Wach, Sociology of Religion (Routledge, 2019), h. 121- 132.

${ }^{12}$ Exoteric is a concept that states that the religions in this world have different manifestations. This difference is caused by the embodiment of history. With this exoteric understanding, religions in the world, especially those that are still alive, appear to have different names, such as Islam, Catholic Christianity, Judaism, Confucianism, Buddhism, Hinduism and so on.

${ }^{13}$ Ftrithjof Schuon, Christianity Islam Perspectives on Esoteric Ecumenism (Jerusalem: Wrod Wisdom, 2008), https://findtruth.co.uk/wp-content/uploads/2020/12/Christianity-Islam_-Perspectives-onEsoteric-Ecumenism-A-New-Translation-with-Selected-Letters-PDFDrive.com-.pdf.

${ }^{14}$ James Goetz, "Theodicy, Supreme Providence, and Semiclassical Theism", Sustainability (Switzerland) 4, 9-1:(2020) 1, https://doi.org/https://doi.org/10.1080/14746700.2020.1825195. Theodicy,.

${ }^{15}$ Ngainun Naim, "Kerukunan Antaragama Perspektif Filsafat Perennial Rekonstruksi Pemikiran Frithjof Schuon", Alqalam 29, 574 :(2012) 3, https://doi.org/10.32678/alqalam.v29i3.860.

${ }^{16}$ Leni Nurmiyanti, "Pendidikan Agama Islam Sebagai Pondasi Sosial Budaya dalam Kemajemukan," Journal ISTIGHNA 1, no. 2 (2018): 62-85, https://doi.org/10.33853/istighna.v1i2.4.

${ }^{17}$ Casram Casram, "Membangun Sikap Toleransi Beragama dalam Masyarakat Plural", Wawasan: Jurnal Ilmiah Agama dan Sosial Budaya 1, 98-187 :(2016) 2, https://doi.org/10.15575/jw.v1i2.588. ${ }^{18}$ Izzuddin \& Ahmad Khoirul Fata, "Realizing the Religion as the Source of Harmony in a Multicultural Society", Kontemplasi: Jurnal Ilmu-Ilmu Ushuluddin 08, 202-171:(2020) 2 .

${ }^{19}$ Alwi Shihab, "Islam Inklusif, Cet," V, Bandung: Mizan, 1999, h. 6.

${ }^{20}$ Abdul Azis, "Pendidikan Humanis dan Inklusif", Munzir 9, 11-1: (2016) 1.
} 
impact (such as economic inequality, legal justice) on the emergence of intolerant attitudes. ${ }^{21}$ that is difficult or reluctant to accept differences in any aspect in the form of an attitude of rejecting differences and racism towards differences in race, culture, ethnicity and religion. ${ }^{22}$ Ideally, religious values should encourage people to be inclusive, not exclusive, while majoritarianism is an attitude of arrogance that considers oneself capable and has the right arbitrarily to minorities.

Data on the phenomenon of intolerance or lack of tolerance $(\mathrm{KBBI})^{23}$ in religion lately is getting stronger and has penetrated the world of education. Several educational institutions are indicated as breeding grounds for intolerance. In (2011) the Institute for the Study of Islam and Peace released that (327 junior high school teachers and 263 high school teachers) showed the spread of the ideology of Islamism among Islamic religious teachers. LaKIP (2015) reveals the existence of intolerance and a strong attitude toward Islamism among teachers and students who are Muslim. The Ministry of Education and Culture conducted this research in July-September 2016 based on the increasing sentiment of religious and racial conflicts in Indonesia, including discrimination and ethnic domination of the majority over minorities.

BNPT (2018) noted that seven state universities were exposed to radicalism. ${ }^{24}$ Meanwhile, the Setara Institute (2019) stated that a total of ten state universities were exposed to radicalism. ${ }^{25}$ The phenomenon of intolerance also occurs in secondary education institutions through the Student Council/Rohis activity unit. However, the results of research on religious moderation education in 2020 at a school in Gorontalo concluded that it was contradictory to this phenomenon that the activities carried out by the Rohis were able to implement tolerance and accommodative attitude towards a local culture with quite good

\footnotetext{
${ }^{21}$ Muhammad Adlin Sila \& Fakhruddin, Indeks kerukunan umat beragama 2019, Balai Penelitian dan Pengembangan Agama Makassar, مج. 19, 2020.

${ }^{22}$ Qowaid, "Gejala Intoleransi Beragama si Kalangan Peserta Didik dan Upaya Penanggulangannya Melalu Pendidikan Agama Islam di Sekolah", Dialog: Jurnal Penelitian dan Kajian Islam 36, 1 (2013).

${ }^{23}$ Kamus Besar Bahasa Indonesia \& Edisi Kedua, "Pusat Pembinaan dan Pengembangan Bahasa", Kamus Besar Bahasa Indonesia, 1997, https://kbbi.kemdikbud.go.id/entri/daring.

${ }^{24}$ Husen Hasan Basri \& Muhamad Murtaddlo, "Indeks karakter siswa 2020", 2019.

${ }^{25}$ Husen Hasan Basri \& Muhamad Murtaddlo, "Indeks karakter siswa 2021", OSF.io 1, 5 :(2019) 1.
} 
scores. ${ }^{26}$ This means that students who have been perceived as intolerant and not accommodating to local culture are still debatable.

The phenomenon of religious conflict in the world of education appears in the aspect of tolerance between students of different religions in an educational institution, which is marked by four indicators: 1) Lack of acceptance (Not accepting opinions, values, behavior of others who are different from oneself ), 2) Disrespect, (does not treat different people well, and does not reduce their rights), 3) Lack of sympathy for the differences in views and attitudes of others or unable to refrain from things that are not approved, 4) Limited freedom religion, that is, everyone is not free to practice and communicate his religious teachings to other people who receive the communication. ${ }^{27}$ The four indicators cannot be separated from the difference factor in understanding religious doctrine and excessive religious fanaticism. ${ }^{28}$

In Gorontalo itself, tolerance is not a new issue. The practice of tolerance in Gorontalo has been entrenched and rooted and has a long historical record. Tolerance is also not an "imported" discourse but comes from local spiritual habits and practices and is based on the tolopani principle, namely local wisdom in respect for fellow human beings.. ${ }^{29}$ However, this principle is not in line with an index of Kerukunan Umat Beragama (KUB) released by the Ministry of Religion in 2019; Gorontalo is at a score of 73.24, ranking 19 among all provinces in Indonesia. ${ }^{30}$

The data on Kerukunan Umat Beragama (KUB) above shows that tolerance in Gorontalo still needs to be improved, even though the majority of Gorontalo's

\footnotetext{
${ }^{26} \mathrm{Hj}$ Mujizatullah, "Pendidikan Moderasi Beragama Peserta didik di Kabupaten Gorontalo", Educandum 6, 61-48:(2020) 1, https://doi.org/https://doi.org/10.31969/educandum.v6i1.325.

${ }^{27}$ Budhy Munawar Rachman, Pendidikan Karakter: Pendidikan Menghidupkan Nilai untuk Pesantren, Madrasah dan Sekolah, Jakarta: Lembaga Sosial Agama dan Filsafat (Jakarta: Lembaga Sosial Agama dan Filsafat (LSAF), 2015), 412-16, https://scholar.google.com/citations?ixOX6EcAAAAJ. ${ }^{28}$ Inayatul Ulya, "Pendidikan Islam Multikultural Sebagai Resolusi Konflik Agama Di Indonesia, Baca: Akar Terbentuknya Konflik Antar Agama Agama", Fikrah 4, 20 :(2016) 1 , https://doi.org/10.21043/fikrah.v4i1.1663.

${ }^{29}$ Punco Tanipu, "Praktik Toleransi di Gorontalo", Punco.Id, 2019, https://www.funco.id/praktiktoleransi-di-gorontalo/.

${ }^{30}$ Sila \& Fakhruddin, Indeks kerukunan umat beragama 2019.
} 
population is Muslim (1,170,793 people) with a heterogeneous society. ${ }^{31}$ However, it is still possible to assume that there is an attitude of intolerance between people or between religious adherents and informal educational institutions. So that the improvement efforts must continue to be carried out through the program prioritas utama (PPU) to improve the quality of indicators from the average dimension of the largest loading factor, namely the dimensions; 1) coaching and 2) facilitation. ${ }^{32}$

In these two dimensions, tolerance between religious communities, with four indicators according to Tillman's theory: (a) respect, (b) patience (c) free and (d) acceptance, ${ }^{33}$ it is important to know the effect, especially when it is associated with output variables in the form of intolerant attitudes: (a) overcoming and (understanding) students in schools who have different beliefs and religions. ${ }^{34}$ With the Tillman indicator, the importance of this research is in addition to describing tolerance between religious communities, intolerant behavior in students, it also aims to test the hypothesis whether there is a significant influence between fostering tolerance between religious communities and intolerant behavior of heterogeneous students in formal educational institutions in Gorontalo City.

\section{B. Interreligious Tolerance}

\section{a. The Concept of Tolerance}

Tolerance is a borrowed language from English "tolerance", but actually comes from Latin "tolerare" while in Arabic it is known as "tasamuh" it means generosity, mutual permission, mutual convenience. ${ }^{35}$ Tolerance is defined as liberality toward the opinions of other; patience with other, Tolerance is also an

\footnotetext{
${ }^{31}$ Hasanudin Hasanudin, "Kerukunan Masyarakat Multikultur Di Desa Banuroja, Gorontalo", AlQalam 24, 18 :(2018) 1, https://doi.org/10.31969/alq.v24i1.465.

${ }^{32}$ Balitbang Diklat Kemenag RI, "laporan Executive Summary Survey Indeks Kerukunan Umat Beragama Tahun 2019", 2019.

${ }^{33}$ Diane G Tillman, "Educating for a culture of peace in refugee camps", Childhood Education 77, 6 78-375:(2001). "Declaring the character of tolerance as an attitude of mutual respect through understanding with the aim of peace"

${ }^{34}$ Diane G Tillman, "Mindful Parenting : Nurturing With Love And Wisdom, Disciplining With Peace And Respect", Proceedings of The 1st Annual Internasional Conference on Islamic Early Childhood Education (Yogyakarta: Study Program of Islamic Education for Early Childhood, 2016), 1-4.

${ }^{35}$ Fatimah Djafar, "Toleransi Antar Umat Beragama dalam Pandangan Katolik dan Islam" (Gorontalo, 2021).
} 
ambivalent concept, namely respecting the beliefs of others even though there is a conflict with one's own understanding of the true religion according to oneself.. Tolerance can also be understood as an attitude of patience and steadfastness, it can even be said that the attitude is not "insist" in the face of differences in belief or religion.. ${ }^{36}$

More clearly, the Ensiklopedi Nasional Indonesia (ENI), defines religious tolerance as an attitude of being willing to accept the diversity and freedom of religion that are embraced and beliefs that are believed by other parties or groups.. ${ }^{37}$

Some of the understandings of tolerance above give a broader meaning to the nature of human freedom to express their beliefs. They practice their religion freely, are respected, and are tolerant of people with different views, beliefs, and other religions.

The essence of tolerance in the inter-religious association, which is based on each religion, is the responsibility of the adherents of that religion and has a form of worship (ritual) with its own system and method, which is assigned (charged) and becomes the responsibility of the adherents on that basis. Tolerance in inter-religious life is not tolerance in religious matters but the embodiment of the religious attitude of adherents of religion in the association of life between people who are not of the same religion, in social problems or in the general benefit.

Referring to Walzer's opinion, tolerance must be able to form possible attitudes, including attitudes to accept differences, change uniformity into diversity, acknowledge the rights of others, respect the existence of others, and enthusiastically support cultural differences and the diversity of God's creation.. 38

\footnotetext{
${ }^{36}$ Ukhiya Rizqiany, "Religious tolerance value analysis perspective teachers of Islam, Christian and Catholic religious education in SMK Demak", Attarbiyah: Journal of Islamic Culture and Education 2, 55-236 :(2017) 2, https://doi.org/10.18326/attarbiyah.v2i2.236-255.

${ }^{37}$ Dewan Ensiklopedi Nasional Indonesia, "Ensiklopedi nasional indonesia", 2004.

${ }^{38}$ Michael Walzer, "La política de la diferencia: estatalidad y tolerancia en un mundo multicultural", Isegoría 0, 53-37 :(1996) 14 , https://doi.org/10.3989/isegoria.1996.i14.210.
} 


\section{b. Tolerance Indicator}

Tillman, provides four tolerance indicators as follows:

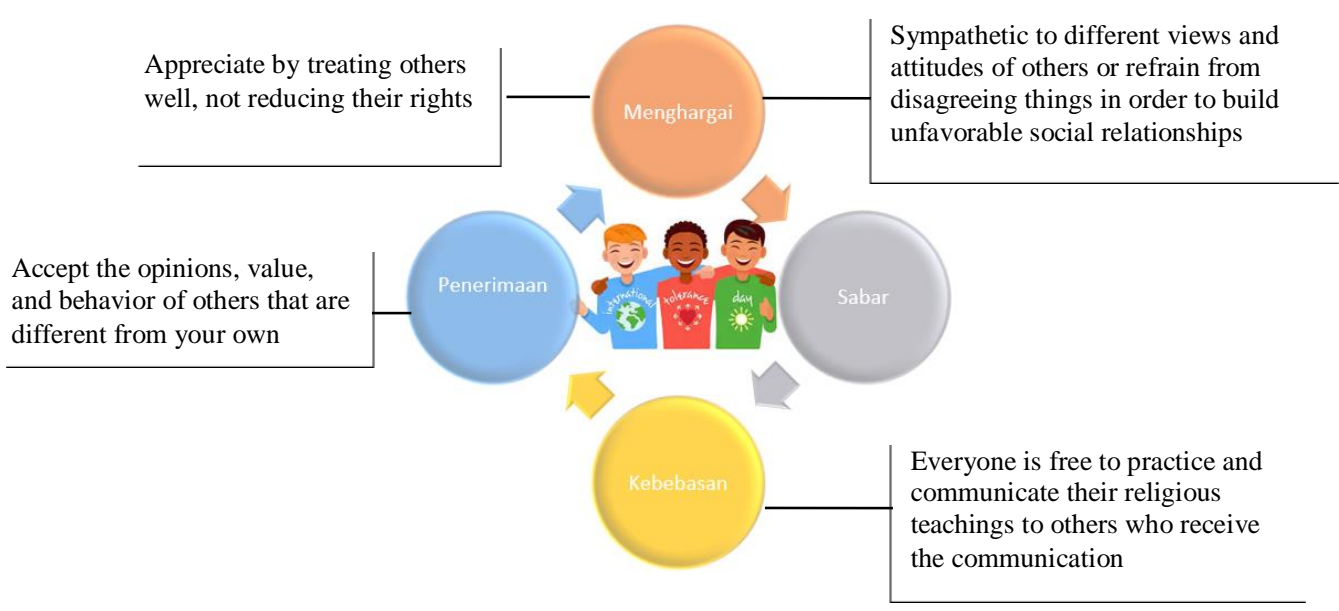

The four indicators of tolerance above align with the tolerance developed by the Gulenist, which makes love the basis of education. Gulen also actualizes it in the form of love, love for others, mutual respect and tolerance. ${ }^{39}$ With that concept, Love and Tolerance, gave created three types of tolerance, namely:;

1) Tolerance, letting others be themselves, respecting others, their origins and backgrounds always mean refusing to talk to others about what to do and not wanting to influence them to follow personal ideas for certain progress.

2) Ideological tolerance, is being able and willing to recognize the right of other minds to defend and practice conflicting religious beliefs.

3) Harmonious tolerance and love for differences, namely the process of respect, appreciation, and acceptance of different beliefs or beliefs or religions without prejudice or discrimination, even though one has the power to reject or deny it, in order to achieve prosperity and harmonious society. At this level, tolerance is based on openness and service to the

\footnotetext{
${ }^{39}$ Muhammad Anas Ma'arif, "Konsep Pemikiran Pendidikan Toleransi Fethullah Gulen", Tribakri Jurnal Pemikiran Keislaman 30, 306-295 https://doi.org/https://doi.org/10.33367/tribakti.v30i2.812.
} 
community so that the actualization of love and tolerance is created without distinction. ${ }^{40}$

Saudi explained that the indicator of religious tolerance in the world of educators is marked by several negation $4 \mathrm{D}$ words and attitudes FDMH ${ }^{41}$

\begin{tabular}{l|l}
\hline \multicolumn{1}{c|}{4 Do not } & \multicolumn{1}{c}{ FDMH } \\
\hline a) $\begin{array}{l}\text { Do not refuse different or } \\
\text { inexperienced people to join. }\end{array}$ & $\begin{array}{l}\text { a) Focus on similarities not on } \\
\text { differences. }\end{array}$ \\
b) Do not want to join in making fun of \\
$\begin{array}{l}\text { people who are different from him. } \\
\text { befending those who are ridiculed or } \\
\text { reproached. }\end{array}$ \\
$\begin{array}{l}\text { c) } \begin{array}{l}\text { Do not laugh at someone's ethnicity, } \\
\text { religion, culture, body size, gender, }\end{array} \\
\text { or sexual orientation. }\end{array}$ & $\begin{array}{l}\text { Mutual respect among others } \\
\text { regardless of ethnicity, religion, race, } \\
\text { and sect. }\end{array}$ \\
$\begin{array}{l}\text { Do not exclusivism that the truest } \\
\text { teaching is only the religion he } \\
\text { embraces }\end{array}$ & d) Help each other in goodness. \\
\hline
\end{tabular}

Munawwar provides general limitations that tolerance must be built on four principles, namely: 1) Mutual respect, 2) Religious Freedom, 3) Acceptance and 4) Positive Thinking and Trustworthy. ${ }^{42}$

\section{c. Shape of Tolerance}

Immature diversity is indicated by the insufficient space available for the perpetrators to live in a divine, social, and human way, thus far from being tolerant. Meanwhile, religiously mature people always produce social behavior that respects human values, consistent morality, non-violence, and other meaningful things. Refers to forms of tolerance, Allport ${ }^{43}$ and $\operatorname{Vogt}^{44}$ give the concept map tolerant personality into six parts, as shown in the following diagram;

\footnotetext{
${ }^{40}$ Supriyanto Supriyanto, "Memahami dan Mengukur Toleransi dari Perspektif Psikologi Sosial", Psikoislamika: Jurnal Psikologi dan Psikologi Islam 15, $23 \quad$ :(2018) 1 , https://doi.org/10.18860/psi.v15i1.6659.

${ }^{41}$ Saudi Patro, "Masyarakat Agama dan Pluralisme Keagamaan", Jakarta: Paramadina, 1997.

${ }^{42}$ Moch. Sya'roni Hasan, "Internalisasi Nilai Toleransi Beragama", E-Journal Univarsitas Islam Darul Ulum Lamongan, 2018, 79-111.

${ }^{43}$ Walzer, "La política de la diferencia: estatalidad y tolerancia en un mundo multicultural". Isegoría 10.3989/isegoria. 1996. i14.210

${ }^{44}$ Chernyaeva Irina Vasil'evna, "International scientific conference", Empirical Research of Students' Tolerance in Extramural and Distance Education (Melbourne, Australia, 2021), 82. Toleransi Vogt adalah penerimaan atas hal-hal yang tidak disetujui atau tidak disukai agar kita dapat berhubungan dan berinteraksi lebih baik dengan orang lain
} 


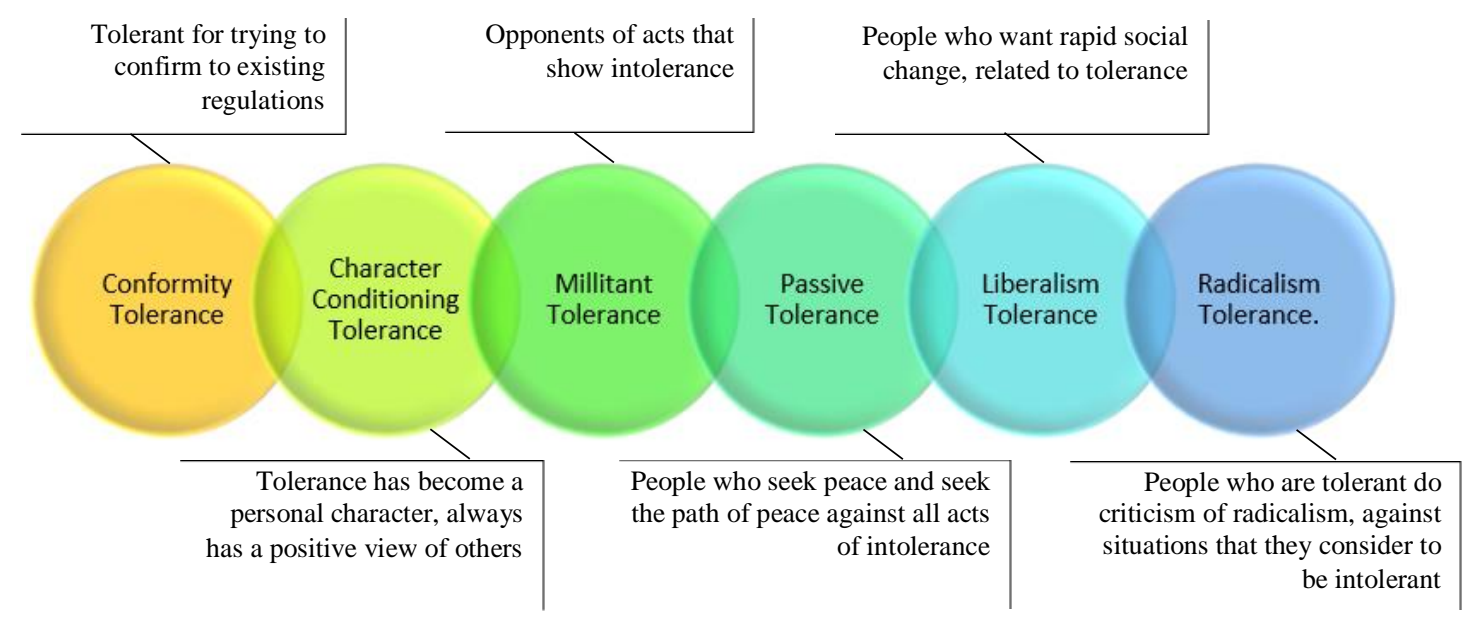

\section{d. Intolerant Behavior}

Intolerance is an "action", not a thought, let alone a rule. ${ }^{45}$ Called tolerant, according to Cohen is a deliberate action by actors with the principle of refraining from intervening (against) their behavior in situations of diversity. 46 Intolerance is a condition when a group (e.g. society, religious group, or nonreligious group) specifically refuses to tolerate religiously-based practices, adherents or beliefs. ${ }^{47}$ However, a statement that a person's religious belief or practice is true while his religion or belief is wrong does not include religious intolerance but ideological intolerance. Intolerance is the opposite of all the principles contained in tolerance. There are at least 3 components of intolerance;

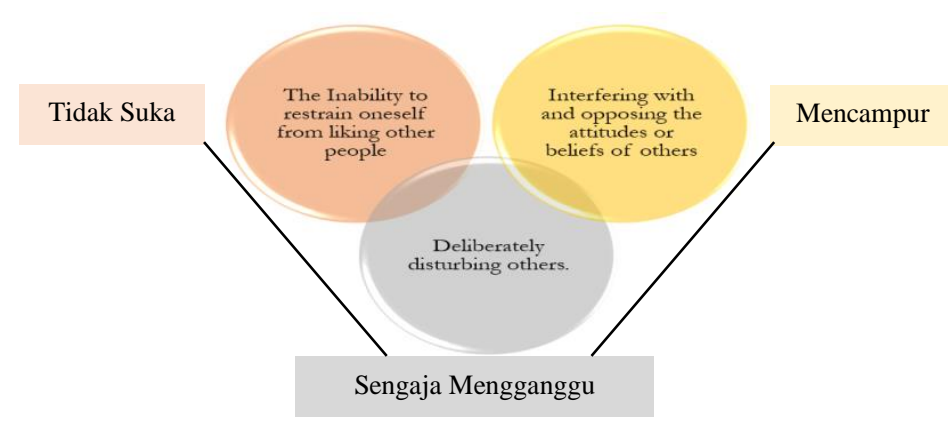

\footnotetext{
${ }^{45}$ Dicky Putra Pratama \& S Ppkn, "Praktik Intoleransi dan Konstruksi Nilai Moral terhadap Pemenuhan Hak Asasi Minoritas", Kajian Moral 1, 19-405:(2017) 1.

${ }^{46}$ S Futaqi, "Konsepsi Dan Limitasi Toleransi Dalam Merayakan Keberagaman Dan Kebebasan Manusia", Annual Conference for Muslim Scholars, 67-156 :(2019) 2 , http://proceedings.kopertais4.or.id/index.php/ancoms/article/view/231.

${ }^{47}$ Kholil Mumtahar, "Pendidikan Toleransi Beragama (Studi Pemikiran KH. Abdurrahman Wahid)" (IAIN Purwokerto, 2021).
} 
Jurgen Habermas, the conceptor of public space, underlined three important points about the ideal public space, namely:

1) Participation and non-discrimination; that is, the public sphere should be a forum open to all.

2) Autonomy; namely, the public sphere, must be autonomous because the autonomous environment is conducive to critical and rational debate.

3) Contains rational or analytical debate, which is the essence of public space. ${ }^{48}$

The three Habermas concepts above ideally give an ultimatum that a common area that accommodates all religious sparks should be without any obstacles. So that antipathy towards certain groups should not occur, especially because of their distinctive religious symbols and expressions, such as; beard, robe, or a woman who wears a hijab and wears a cross.

\section{Method}

This type of research is quantitative research, using a correlational approach $^{49}$ to find out the relationship between the independent and dependent variables. Data was collected using a closed-type questionnaire, which consisted of 25 statement items about religious tolerance and 10 statement items about intolerant behavior. This study involved 67 of 675 students at SMPN 1 Gorontalo City as a truly representative sampling with a random sampling of $10 \%-15 \% .^{50}$ The reason for choosing this location is because it has a large population with a level of religious belief representing five religions, namely; Islam (M 273 - F 337=574), Christian (M 23 - F 27=50), Catholic (M 2), and Hindu (M 2 - F 1=3), Buddhist (M 5 - F 6=11), ${ }^{51}$ and very relevant to the research title.

Before being distributed to respondents, the researchers conducted a test of the instrument, including the validity test and questionnaire reliability test.

\footnotetext{
${ }^{48}$ Elina Minnullina \& Zhanna Vavilova, "Tolerance as Core Value and Communication Principle", Rethinking Social Action. Core Values in Practice 1, April 2017 (2017): 527-38, https://doi.org/10.18662/lumproc.rsacvp2017.48.

${ }^{49}$ Nana Syaodih, "Metode penelitian pendidikan", Bandung: PT. Remaja Rosdakarya, 2009.

${ }^{50}$ Mardalis, Metode Penelitian: Suatu Pendekatan Proposal, 12 . (Jakarta: Bumi Aksara, 2010), h.57

${ }^{51}$ https://sekolah.data.kemdikbud.go.id/index.php/chome/profil/b041dcd0-6585-e111-b570-

$\underline{\mathrm{f} 3 \mathrm{fb} 13809714}$
} 
Validity test using SPSS type 16 program, ${ }^{52}$ while the reliability test using Cronbach Alpha, which is a reliability measure that has a value ranging from zero to one. ${ }^{53}$ Before conducting data analysis, the first thing a researcher did was to test the statement items so that the instrument was declared valid. Here is the working process of the validation test:

1. Determine the score for each item and the total score (the total score of all items);

2. Item score as $\mathrm{X}$ value and total score as $\mathrm{Y}$;

3. Determine the validity index of each item (X) with a total score (Y);

4. The minimum requirement to be considered a valid instrument item is the validity index value $\geq 0,3$.

The data analysis technique in this study uses the Normality and Linearity Test, and then a simple linear regression analysis is carried out $(Y=a+b X)$. After getting the results from the regression analysis, the researcher interprets the results obtained, which will then be able to know the extent of the influence of the level of religious tolerance on the intolerant behavior of the students of SMP N 1 Gorontalo City.
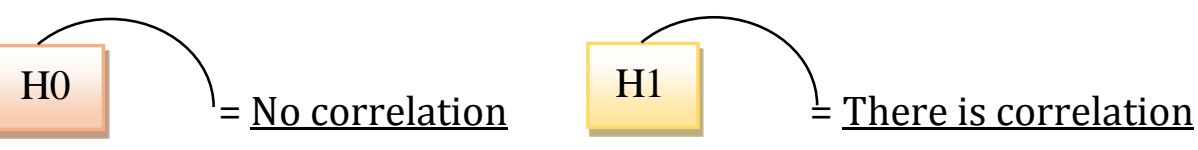

Decision making in the correlation hypothesis is by looking at the significance value (probability/possibility). Probability is embodied in a value used to measure the level of occurrence of a random event. ${ }^{54}$ Referring to Sugiyono's statement 55 and Arikunto, ${ }^{56}$ that if the significance value (Sig.) $>0,05$, then $\mathrm{H}_{0}$ accepted. If the significance value (Sig.) $<0,05$, then $\mathrm{H}_{0}$ rejected ${ }^{57}$ rejection criteria

\footnotetext{
${ }^{52}$ Andrew M Colman \& Briony D Pulford, A crash course in SPSS for Windows: updated for versions 14, 15, and 16 (John Wiley \& Sons, 2011).

53James Dean Brown, "The Cronbach alpha reliability estimate", JALT Testing \& Evaluation SIG Newsletter 6, 1 (2002).

${ }^{54}$ Lian G Otaya, "Probabilitas Bersyarat, Independensi dan Teorema Bayes Dalam Menentukan Peluang Terjadinya Suatu Peristiwa", Jurnal Manajemen Pendidikan Islam 4, 78-68:(2016) 1 .

${ }^{55}$ Sugiyono Sugiyono, "Metode penelitian kuantitatif dan kualitatif dan R\&D" (Alfabeta Bandung, 2010).

${ }^{56}$ Suharsimi Arikunto, Dasar-Dasar Evaluasi Pendidikan Edisi 3 (Bumi Aksara, 2021).

${ }^{57}$ Adi Setiawan, Pengantar Teori Probabilitas (Salatiga: Tisara Grafika, 2015), h. 20.
} 
$\mathrm{H}_{0}$ is if $\mathrm{r}_{\text {count }}$ smaller than the table, then $\mathrm{H}_{0}$ valid. But on the other hand, if $\mathrm{r}_{\text {count }}$ greater than $\mathrm{r}_{\text {table }}$ then and $\mathrm{H}_{\mathrm{a}}$ declared invalid.

\section{Research Result}

The research results on religious tolerance and intolerant behavior of students at SMP N 1 Gorontalo City were obtained using a questionnaire instrument distributed to students as respondents, totalling 67 students. Before the questionnaire instrument is used for research, it is necessary to test the level of validity and reliability. The number of question items used in the questionnaire instrument trial was 25 statement items about religious tolerance and 10 statement items about intolerant behavior distributed to 67 students of SMP N 1 Gorontalo City.

The results of the trial of the instrument, from 25 items of questions about the questionnaire instrument of religious tolerance, obtained 9 items which were declared valid and reliable, and from 10 items about the instrument of questionnaire on intolerant behavior, obtained 10 questions which were declared valid and reliable.

From the test results of the questionnaire instrument, then 9 items of questionnaire instrument about religious tolerance and 10 items of questionnaire instrument on intolerant behavior were taken, then distributed to 67 students of SMP N 1 Gorontalo City as respondents in conducting research..

\section{Validity and Reliability Test}

a. Validity test

Based on the calculation of the questionnaire instrument test on religious tolerance, the validity of the questionnaire was obtained as many as 9 valid questionnaire statements. While the questionnaire instrument test on intolerant behavior, obtained the validity of the questionnaire as many as 10 valid statements. 
Table 1.1

Results of the Validity of the Questionnaire Trial Level of Religious Tolerance

\begin{tabular}{|c|c|c|c|}
\hline No & $\begin{array}{l}\text { Corrected item-total } \\
\text { correlation }\end{array}$ & $r$ table & Ket \\
\hline 1 & 2 & 3 & 4 \\
\hline 1 & 0.422 & 0.244 & Invalid \\
\hline 2 & 0.336 & 0.244 & Invalid \\
\hline 3 & 0.198 & 0.244 & Invalid \\
\hline 4 & 0.214 & 0.244 & Invalid \\
\hline 5 & 0.424 & 0.244 & Invalid \\
\hline 6 & $.711^{* *}$ & 0.244 & Valid \\
\hline 7 & $.518^{*}$ & 0.244 & Valid \\
\hline 8 & $.459^{*}$ & 0.244 & Valid \\
\hline 9 & 0.237 & 0.244 & Invalid \\
\hline 10 & $.462^{*}$ & 0.244 & Valid \\
\hline 11 & 0.261 & 0.244 & Invalid \\
\hline 12 & 0.055 & 0.244 & Invalid \\
\hline 13 & 0.133 & 0.244 & Invalid \\
\hline 14 & 0.026 & 0.244 & Invalid \\
\hline 15 & 0.377 & 0.244 & Invalid \\
\hline 16 & $.612^{* *}$ & 0.244 & Valid \\
\hline 17 & -0.043 & 0.244 & Invalid \\
\hline 18 & 0.103 & 0.244 & Invalid \\
\hline 19 & $.599^{* *}$ & 0.244 & Valid \\
\hline 20 & $.468^{*}$ & 0.244 & Valid \\
\hline 21 & $.591^{* *}$ & 0.244 & Valid \\
\hline 22 & 0.139 & 0.244 & Invalid \\
\hline 23 & 0.073 & 0.244 & Invalid \\
\hline 24 & 0.424 & 0.244 & Invalid \\
\hline 25 & $.511^{*}$ & 0.244 & Valid \\
\hline
\end{tabular}

Source: Output SPSS 16.0

The results of the validity of the questionnaire test on the level of religious tolerance of students if the validity index value is $\geq 0,3$, then the questionnaire statement item is said to be valid. Based on the results of the validation test in the table above, it shows that the number of valid statement items is nine items. Which means that the statements that can be used in this study are nine items. While the rest are declared invalid 
because they do not meet the requirements of a statement item being said to be valid or in other words that the validity index value is $\leq 0,3$

Tabel 1.2 Intolerance Behavior Test Validity Results

\begin{tabular}{cccc} 
No & $\begin{array}{c}\text { Corrected item-total } \\
\text { correlation }\end{array}$ & r tabel & Ket \\
\hline $\mathbf{1}$ & $\mathbf{2}$ & $\mathbf{3}$ & $\mathbf{4}$ \\
\hline 1 & $.860^{* *}$ & 0.244 & Valid \\
\hline 2 & $.674^{* *}$ & 0.244 & Valid \\
\hline 3 & $.698^{* *}$ & 0.244 & Valid \\
\hline 4 & $.832^{* *}$ & 0.244 & Valid \\
\hline 5 & $.789^{* *}$ & 0.244 & Valid \\
\hline 6 & $.694^{* *}$ & 0.244 & Valid \\
\hline 7 & $.803^{* *}$ & 0.244 & Valid \\
\hline 8 & $.799^{* *}$ & 0.244 & Valid \\
\hline 9 & $.789^{* *}$ & 0.244 & Valid \\
\hline 10 & $.581^{* *}$ & 0.244 & Valid \\
\hline$S 0 u r c:$ OutputSPSS 16.0 & & \\
\hline
\end{tabular}

Source: Output SPSS 16.0

The results of the validity test of the Intolerance Behavior instrument above, show that of the 10 statement items tested, it can be seen that all of the items are declared valid. Based on the results of the validation test above, as a whole, it can be seen that the total item statements in the valid instrument are 19 items. For variable $\mathrm{X}$ there are 9 items and for variable $\mathrm{Y}$ there are 10 items.

\section{b. Reliability Test}

The alpha reliability value is located in the column reliability statistic table cronbach alpha. Then score on cronbach alpha obtained were consulted with the level of significance 5\%. When the score cronbach alpha> 5\% then the statement item on the instrument is stated reliabel.

Table 1.3

Reliability Results of the Questionnaire Trial Level of Religious Tolerance

\begin{tabular}{c|c}
\hline \multicolumn{2}{c}{ Reliability Statistics } \\
\hline $\begin{array}{c}\text { Cronbach's } \\
\text { Alpha }\end{array}$ & N of Items \\
\hline .755 & 9 \\
\hline
\end{tabular}

The results of the calculation of the reliability test obtained that the reliability value of the religious tolerance questionnaire is, cronbach alpha = 
0,755 or $75,5 \%$ with significance level $5 \%$. Because cronbach alpha> $5 \%$ it can be concluded that the instrument is reliable.

Table 1.4

\begin{tabular}{|c|c|c|}
\hline \multicolumn{3}{|c|}{$\begin{array}{c}\text { Reliability Test Results Intolerance } \\
\text { Behavior Reliability Statistics }\end{array}$} \\
\hline \multirow[b]{4}{*}{ Cronbach's Alpha } & Cronbach's Alpha & \\
\hline & Based on & \\
\hline & Standardized & \\
\hline & Items & $\mathrm{N}$ of Items \\
\hline .913 & .915 & 10 \\
\hline
\end{tabular}

The reliability value of the intolerant behavior questionnaire is cronbach alpha $=0,913$ or 91,3\% with significance level 5\%. Because Cronbach Alpha> $5 \%$, it can be concluded that the instrument is reliable. Based on the results of the validity and reliability tests, it can be concluded that the statement items in the instrument can be used.

\section{Normality And Linearity Test}

The purpose of using the normality test is to determine whether the data comes from a normally distributed population or not. The data used in this normality test are religious tolerance data (X) and intolerant behavior data (Y). For the normality testing technique, the researcher uses the KolmogorovSmirnov ${ }^{58} \mathrm{Z}$ calculated with the help of SPSS type 16. The basis for decision making refers to 2 things, namely:

1) If value Sig. $>0.05$, then normal distribution

2) If value Sig. $<0.05$, then it is not normally distributed

\footnotetext{
${ }^{58}$ Source Journal, American Statistical, \& No Mar, "The Kolmogorov-Smirnov Test for Goodness of Fit Author ( s ): Frank J . Massey, Jr . Published by: Taylor \& Francis , Ltd . on behalf of the American Statistical Association Stable URL : http://www.jstor.org/stable/2280095", Journal of the American Statistical Association 46, 78-68:(2017) 253.
} 
a. Normality test

Table 1.5

Normality Test Results One-Sample Kolmogorov-Smirnov Test

\begin{tabular}{llr}
\hline \multicolumn{2}{c}{ One-Sample Kolmogorov-Smirnov Test } \\
\hline $\mathrm{N}$ & & Unstandardized Residual \\
\hline Normal Parametersa & Mean & 67 \\
& Std. Deviation & .0000000 \\
Most Extreme Differences & Absolute & 2.61076054 \\
& Positive & .089 \\
& Negative & .067 \\
Kolmogorov-Smirnov Z & & -.089 \\
Asymp. Sig. (2-tailed) & & .726 \\
\hline a. Test distribution is Normal. & & .667 \\
\hline
\end{tabular}

Based on the calculation of the normality test with Kolmogorov Smirnov $Z$ on the independent variable, namely religious tolerance $(\mathrm{X})$ and on the dependent variable, namely intolerant behavior $(Y)$, the results of the normality test calculation with a value of KSZ in the amount of 0,726 and Asymp.Sig. in the amount of 0,667 greater than 0,05 , then it can be concluded that the data is normally distributed.

\section{b. Linearity Test}

This linearity test aims to determine whether the two variables have a linear relationship or not significantly. A linear relationship illustrates that changes in the predictor variable will tend to be followed by changes in the criterion variable by forming a linear line.

Table 1.6

\section{Linearity Test Result}

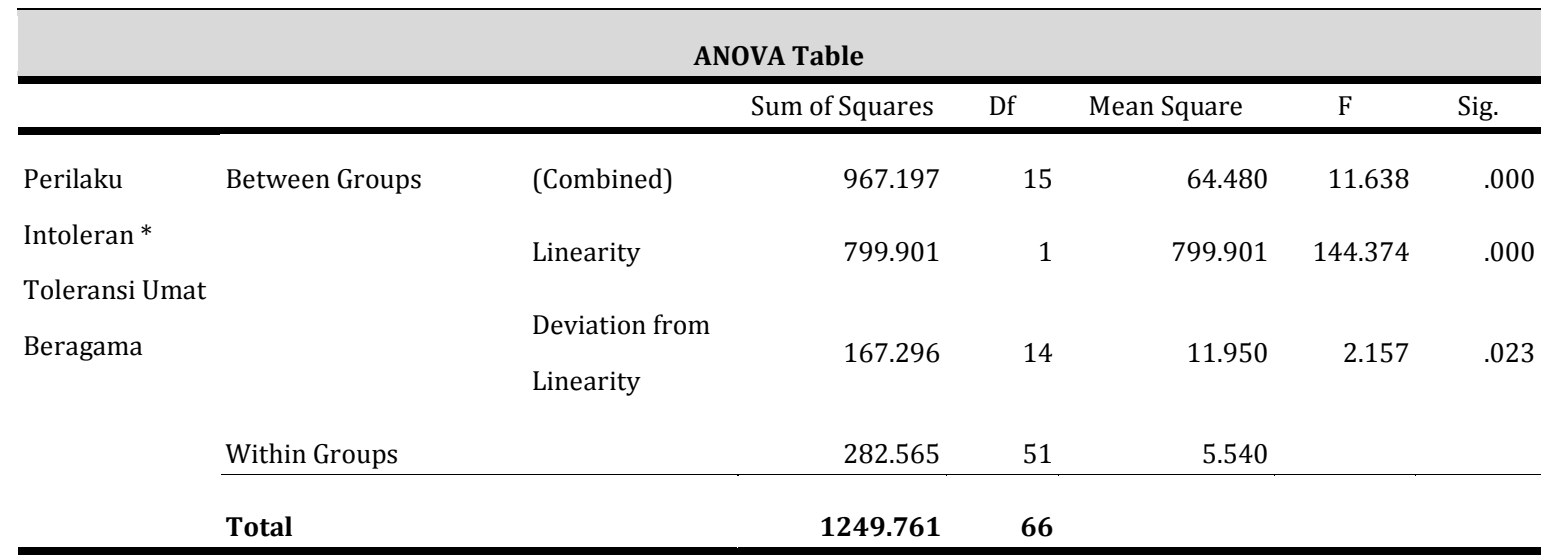


The results of the linearity test calculation can be seen that the significance results on the Linearity line are 0,000 smaller than 0,05 and the result of significance on the line Deviation from Linearity is as big as 0,23 greater than 0,05 . The data above concludes a linear relationship between the religious tolerance variable and the intolerant behavior variable.

\section{Simple Linear Regression Analysis}

Simple linear regression analysis is used to test the effect of the independent variable on the dependent variable. In this study, the independent variable is tolerance between religious communities and the dependent variable is intolerant behavior. On the basis of decision making refers to 2 things, namely comparing the significant value with a probability value of 0.05 . a) If value Sig. < 0.05 , then the variable of tolerance between religious communities affects the intolerant behavior of students, b) if value Sig. $>0.05$, then the inter-religious tolerance variable has no effect on the intolerant behavior of students.

\section{Table 1.7}

ANOVA

\begin{tabular}{|c|c|c|c|c|c|c|}
\hline \multicolumn{2}{|c|}{ Model } & $\begin{array}{l}\text { Sum of } \\
\text { Squares }\end{array}$ & Df & Mean Square & \multirow{2}{*}{$\frac{\mathbf{F}}{115.577}$} & \multirow{2}{*}{$\begin{array}{l}\text { Sig. } \\
.000^{\mathrm{a}}\end{array}$} \\
\hline 1 & Regression & 799.901 & 1 & 799.901 & & \\
\hline & Residual & 449.861 & 65 & 6.921 & & \\
\hline & Total & 1249.761 & 66 & & & \\
\hline
\end{tabular}

a. Predictors: (Constant), Religious Tolerance (X)

From table 12 obtained the value of $F=115,577$ with value Sig in the amount of 0,000 . Because $F_{\text {tabel }}=3,99$ and $F_{\text {hitung }}=115,577$ means $F_{\text {hitung }}>F_{\text {tabel }}$ so $\mathrm{H}_{0}$ is rejected. Value Sig. in the amount of $0,000<0,05$ so that $\mathrm{H}_{0}$ is rejected. So it can be concluded that inter-religious tolerance affects the intolerant behavior of students in SMP N 1 Gorontalo City.

Table 1.9

Model Summary

\begin{tabular}{ccccc}
\hline Model & R & R Square & Adjusted R Square & Std. Error of the Estimate \\
\hline 1 & $0.800^{\mathrm{a}}$ & 0.640 & 0.635 & 2.63077 \\
\hline
\end{tabular}

a. Predictors: (Constant), Religious Tolerance (X) 
From table 13 , the results of $R=0.800$ mean that there is a significant relationship between religious tolerance and intolerant behavior. While the value of determination (R Square) of 0.640 means that the contribution of religious tolerance in influencing intolerant behavior is $64 \%$.

Table 1.10

Coefficients ${ }^{a}$

\begin{tabular}{|c|c|c|c|c|c|c|}
\hline \multirow{2}{*}{\multicolumn{2}{|c|}{ Model }} & \multicolumn{2}{|c|}{$\begin{array}{l}\text { Unstandardized } \\
\text { Coefficients }\end{array}$} & \multirow{2}{*}{$\begin{array}{c}\text { Standardized } \\
\text { Coefficients } \\
\text { Beta }\end{array}$} & \multirow[b]{2}{*}{$\mathbf{t}$} & \multirow[b]{2}{*}{ Sig. } \\
\hline & & B & Std. Error & & & \\
\hline 1 & (Constant) & 11.106 & 2.990 & & 3.715 & .000 \\
\hline & $\begin{array}{l}\text { Toleransi Umat } \\
\text { Beragama (X) }\end{array}$ & .820 & .076 & .800 & 10.751 & .000 \\
\hline
\end{tabular}

a. Dependent variabel: perilaku intoleran (Y)

From table 1.10, the constant value $=11.106$ and the variable coefficient value $\mathrm{X}=0.820$, so the regression equation is $\mathrm{Y}=11.106+0.820 \mathrm{X}$. Based on Sig. $=$ $0.000<0.05$, then $\mathrm{H}_{0}$ is rejected which means that tolerance between religious communities has a significant effect on intolerant behavior in students at SMP N 1 Gorontalo City.

\section{Concluding Remarks}

The results obtained from hypothesis testing indicate that there is a significant influence between tolerance between religious believers and the intolerant behavior of students at SMP N 1 Gorontalo City. This condition means that the higher the tolerance of religious people, the better the intolerant behavior of students. And vice versa, the lower the tolerance of religious people, the worse the intolerant behavior of students.

The results of the study prove that religious tolerance affects the intolerant behavior of students. This means that although students at SMP N 1 Gorontalo City have different beliefs, they highly value harmony between students, respect each other, help each other, and get along well..

Furthermore, the results of the determination value (R Square) illustrate that the contribution of tolerance between religious communities affects the intolerant behavior of students at SMP N 1 Gorontalo City in this study. The rest is determined by other factors not disclosed in this study. 
The fostering of religious tolerance with the intolerant behavior of students at SMPN 1 Gorontalo City is shown that although students in schools have different beliefs, they still respect each other's religions. This study provides evidence that religious tolerance can show intolerant students' behaviour in schools, as indicated by a regression model number of F-count 115.577 with a significance level of 5\% (Ftabel $=3.99$ ).

The correlation test above of 0.5 supports the results of this study, this means that there is a relationship between fostering tolerance and intolerant behavior. Likewise, the coefficient column shows that if tolerance development is carried out optimally, programmed and integrated, it is believed to affect efforts to reduce intolerant behavior, both between students and between teachers and students of different religions. Thus, the implications based on the regression model obtained from this study explain that if the value of the tolerance building variable is not fixed, then the value of intolerant behavior does not change (low) according to the constant value. But if the value of tolerance development is fixed, then the change value will increase according to the value of intolerant behavior contained in the $5 \%$ alpha determination.

This study uses two variables, namely fostering tolerance between religious communities as variable $\mathrm{X}$ and intolerant behavior as variable $\mathrm{Y}$. In fostering tolerance between religious communities, there are four indicators, namely: 1) appreciation; 2) patience; 3) freedom; 4) reception. Based on the results of the study that the supporting indicators of variable X can be seen in the results of the linearity test stating that the development of tolerance between religious communities affects the intolerant behavior of students in SMP N 1 Gorontalo City which refers to two indicators, namely: 1) coping and 2) understanding. This means that efforts to foster tolerance between religious communities carried out on heterogeneous students should continue to be carried out systematically and programmed. Because inter-religious harmony in educational institutions must also be supported by an integrated school curriculum in subjects, besides that the school must ensure the creation of a harmonious religious life atmosphere without distinguishing between students of different beliefs, so that the concept of "for you your religion and for me My religion" aims to provide space for students to 
worship and practice their religion according to their beliefs. This is where the importance of human values from all plural beliefs, in order to realize the love of harmony in educational institutions.

\section{References}

Alamsyah, Ichsan Emrald. "Moderasi Beragama dalam Menangkal Paham Radikalisme". $\quad$ Republika,

2021. https://www.republika.co.id/berita/r25c05349/moderasi-beragamadalam-menangkal-paham-radikalisme.

Arikunto, Suharsimi. Dasar-Dasar Evaluasi Pendidikan Edisi 3. Bumi Aksara, 2021.

Azis, Abdul. "Pendidikan Humanis dan Inklusif". Munzir 9, 11-1:2016) 1 .

Balitbang Diklat Kemenag RI. "laporan Executive Summary Survey Indeks Kerukunan Umat Beragama Tahun 2019", 2019.

Basri, Husen Hasan, dan Muhamad Murtaddlo. "Indeks karakter siswa 2020", 2019.

_—_. "Indeks karakter siswa 2021". OSF.io 1, 5 :(2019) 1.

Brown, James Dean. "The Cronbach alpha reliability estimate". JALT Testing \& Evaluation SIG Newsletter 6, 1 (2002).

Casram, Casram. "Membangun Sikap Toleransi Beragama dalam Masyarakat Plural". Wawasan: Jurnal Ilmiah Agama dan Sosial Budaya 1,-187 :2016) 2 98. https://doi.org/10.15575/jw.v1i2.588.

Colman, Andrew M, dan Briony D Pulford. A crash course in SPSS for Windows: updated for versions 14, 15, and 16. John Wiley \& Sons, 2011.

Djafar, Fatimah. "Toleransi Antar Umat Beragama dalam Pandangan Katolik dan Islam". Gorontalo, 2021.

Fadly, Haeri. "MULTIKULTURAL ( Melacak Konsep Multikulturalisme dalam Islam )" 3, 84-71:(2010) 1 .

Fata, Ahmad Khoirul. "Menguak Islam Eksklusif yang Toleran". ISLAMICA: Jurnal $\begin{array}{llll}\text { Studi } & \text { Keislaman } & 6,14 & \end{array}$ https://doi.org/10.15642/islamica.2011.6.1.14-24.

Futaqi, S. "Konsepsi Dan Limitasi Toleransi Dalam Merayakan Keberagaman Dan Kebebasan Manusia". Annual Conference for Muslim Scholars, :(2019) 2 67-156. http://proceedings.kopertais4.or.id/index.php/ancoms/article/view/231.

Goetz, James. "Theodicy, Supreme Providence, and Semiclassical Theism". Sustainability $\quad$ (Switzerland) 4, $4-1 \quad$ :(2020) 1 . https://doi.org/https://doi.org/10.1080/14746700.2020.1825195. Theodicy,.

Hasan, Moch. Sya'roni. "Internalisasi Nilai Toleransi Beragama". E-Journal 
Univarsitas Islam Darul Ulum Lamongan, 2018, 79-111.

Hasanudin, Hasanudin. "Kerukunan Masyarakat Multikultur Di Desa Banuroja, Gorontalo". Al-Qalam 24, https://doi.org/10.31969/alq.v24i1.465.

Imam Bukhori. "Membumikan Multikulturalisme". HUMANISTIKA: Jurnal Keislaman $\quad 5, \quad 40-13 \quad$ (2019) https://doi.org/10.36835/humanistika.v5i1.40.

Indonesia, Dewan Ensiklopedi Nasional. "Ensiklopedi nasional indonesia", 2004.

Indonesia, Kamus Besar Bahasa, dan Edisi Kedua. "Pusat Pembinaan dan Pengembangan Bahasa". Kamus Besar Bahasa Indonesia, 1997. https://kbbi.kemdikbud.go.id/entri/daring.

Itsram. "Toleransi Beragama Indonesia: Bagaikan Gajah di Pelupuk Mata". Institut Sepuluh November, 2021. https://www.its.ac.id/news/2021/09/25/toleransi-beragama-indonesiabagaikan-gajah-di-pelupuk-mata/.

Izzuddin, dan Ahmad Khoirul Fata. "Realizing the Religion as the Source of Harmony in a Multicultural Society". Kontemplasi: Jurnal Ilmu-Ilmu Ushuluddin 08, 202-171:(2020) 2 .

Journal, Source, American Statistical, dan No Mar. "The Kolmogorov-Smirnov Test for Goodness of Fit Author ( $\mathrm{s}$ ): Frank J . Massey, Jr . Published by : Taylor \& Francis , Ltd . on behalf of the American Statistical Association Stable URL : http://www.jstor.org/stable/2280095". Journal of the American Statistical Association 46, 78-68:2017) 253.

Laptah, Tim Penulis. "Laporan Tahunan KOMNAS HAM 2017-2022". Menteng Jakarta Pusat, 2019. https://www.komnasham.go.id/files/20201209laporan-tahunan-komnas-ham-2019-\$V1GFW5HE.pdf.

Ma'arif, Muhammad Anas. "Konsep Pemikiran Pendidikan Toleransi Fethullah Gulen". Tribakri Jurnal Pemikiran Keislaman 30, 306-295 :2019) 2 . https://doi.org/https://doi.org/10.33367/tribakti.v30i2.812.

Mardalis. Metode Penelitian: Suatu Pendekatan Proposal. 12 . Jakarta: Bumi Aksara, 2010.

Minnullina, Elina, dan Zhanna Vavilova. "Tolerance as Core Value and Communication Principle". Rethinking Social Action. Core Values in Practice 1, April 2017 (2017): 527-38. https://doi.org/10.18662/lumproc.rsacvp2017.48.

Muharom, Fauzi. "Tasamuh E-Module Development in the Fiqih Subject for 10 th Grade Students in Islamic Senior". Nazhruna: Jurnal Pendidikan Islam 4, 3 46-531 :(2021). https://doi.org/https://doi.org/10.31538/nzh.v4i3.1617.

Mujizatullah, Hj. "Pendidikan Moderasi Beragama Peserta didik di Kabupaten Gorontalo". Educandum 6, 61-48 :(2020) 1 . https://doi.org/https://doi.org/10.31969/educandum.v6i1.325. 
Mumtahar, Kholil. "Pendidikan Toleransi Beragama (Studi Pemikiran KH. Abdurrahman Wahid)". IAIN Purwokerto, 2021.

Naim, Ngainun. "Kerukunan Antaragama Perspektif Filsafat Perennial Rekonstruksi Pemikiran Frithjof Schuon". Alqalam 29, 574 :2012) 3 . https://doi.org/10.32678/alqalam.v29i3.860.

Nurmiyanti, Leni. "Pendidikan Agama Islam Sebagai Pondasi Sosial Budaya Dalam Kemajemukan". Journal ISTIGHNA 1, 85-62 :(2018) 2 . https://doi.org/10.33853/istighna.v1i2.4.

Otaya, Lian G. "Probabilitas Bersyarat, Independensi dan Teorema Bayes Dalam Menentukan Peluang Terjadinya Suatu Peristiwa". Jurnal Manajemen Pendidikan Islam 4, 78-68:2016) 1.

Patro, Saudi. "Masyarakat Agama dan Pluralisme Keagamaan". Jakarta: Paramadina, 1997.

Pratama, Dicky Putra, dan S Ppkn. "Praktik Intoleransi dan Konstruksi Nilai Moral terhadap Pemenuhan Hak Asasi Minoritas". Kajian Moral 1, -405:2017) 1 19.

Qowaid. "Gejala Intoleransi Beragama si Kalangan Peserta Didik dan Upaya Penanggulangannya Melalu Pendidikan Agama Islam di Sekolah". Dialog: Jurnal Penelitian dan Kajian Islam 36, 1 (2013).

Rachman, Budhy Munawar. Pendidikan Karakter: Pendidikan Menghidupkan Nilai untuk Pesantren, Madrasah dan Sekolah, Jakarta: Lembaga Sosial Agama dan Filsafat. Jakarta: Lembaga Sosial Agama dan Filsafat (LSAF), 2015. https://scholar.google.com/citations?ixOX6EcAAAAJ.

Rizqiany, Ukhiya. "Religious tolerance value analysis perspective teachers of Islam, Christian and Catholic religious education in SMK Demak". Attarbiyah: Journal of Islamic Culture and Education 2, 55-236 :(2017) 2 . https://doi.org/10.18326/attarbiyah.v2i2.236-255.

Schuon, Ftrithjof. Christianity Islam Perspectives on Esoteric Ecumenism. Jerusalem: Wrod Wisdom, 2008. https://findtruth.co.uk/wpcontent/uploads/2020/12/Christianity-Islam_-Perspectives-on-EsotericEcumenism-A-New-Translation-with-Selected-Letters-PDFDrive.com-.pdf.

Setiawan, Adi. Pengantar Teori Probabilitas. Salatiga: Tisara Grafika, 2015.

Shihab, Alwi. "Islam Inklusif, Cet". V, Bandung: Mizan, 1999.

Sila, Muhammad Adlin, dan Fakhruddin. Indeks kerukunan umat beragama 2019. Balai Penelitian dan Pengembangan Agama Makassar. 2020 ,19 ..

Sofiah. "Dialog sebagai media Integrasi Pluralitas dalam Islam". Al Qodiri : Jurnal Pendidikan, Sosial dan Keagamaan 2, 62-50:2017) 1 .

Statistik, Badan Pusat. "Gorontalo, Jumlah Penduduk Menurut Agama (Jiwa), 20182020". BPS Provinsii Gorontalo, 2021. https://gorontalo.bps.go.id/indicator/108/79/1/jumlah-pendudukmenurut-agama.html. 
Sugiyono, Sugiyono. "Metode penelitian kuantitatif dan kualitatif dan R\&D". Alfabeta Bandung, 2010.

Supriyanto, Supriyanto. "Memahami dan Mengukur Toleransi dari Perspektif Psikologi Sosial". Psikoislamika : Jurnal Psikologi dan Psikologi Islam 15, 1 23 :(2018). https://doi.org/10.18860/psi.v15i1.6659.

Syaodih, Nana. "Metode penelitian pendidikan". Bandung: PT. Remaja Rosdakarya, 2009.

Syarif, M. Zainul Hasani. "Dinamika Pendidikan Islam Minoritas (Eksistensi, Kontestasi dan Konvergensi Lembaga Pendidikan Tinggi Muhammadiyah di Nusa Tenggara Timur) Diajukan". UIN Syratif Hidayatullah, 2021.

Tanipu, Punco. "Praktik Toleransi di Gorontalo". Punco.Id, 2019. https://www.funco.id/praktik-toleransi-di-gorontalo/.

Tillman, Diane G. "Educating for a culture of peace in refugee camps". Childhood Education 77, 78-375:(2001) 6.

_-_. "Mindful Parenting : Nurturing With Love And Wisdom , Disciplining With Peace And Respect". Proceedings of The 1st Annual Internasional Conference on Islamic Early Childhood Education, 1-4. Yogyakarta: Study Program of Islamic Education for Early Childhood, 2016.

Ulya, Inayatul. "Pendidikan Islam Multikultural Sebagai Resolusi Konflik Agama Di Indonesia, Baca: Akar Terbentuknya Konflik Antar Agama Agama". Fikrah 4, 20 :2016) 1. https://doi.org/10.21043/fikrah.v4i1.1663.

Vasil'evna, Chernyaeva Irina. "International scientific conference". Empirical Research of Students' Tolerance in Extramural and Distance Education, 82. Melbourne, Australia, 2021.

Wach, Joachim. Sociology of religion. Routledge, 2019.

___. "The comparative study of religions". A Columbia paperback, 1961.

Walzer, Michael. "La política de la diferencia: estatalidad y tolerancia en un mundo multicultural". Isegoría $\quad 0, \quad 53-37$ https://doi.org/10.3989/isegoria.1996.i14.210. 